\title{
Energy costs of daily activities for women in rural India
}

\author{
Shobha Rao*, Medha Gokhale and Asawari Kanade \\ Agharkar Research Institute, GG Agarkar Road, Pune 41 1004, India
}

Submitted 26 January 2006: Accepted 19 August 2006: First published online 13 June 2007

\begin{abstract}
Objective: In view of the paucity of data on energy costs, the present study aimed to estimate these for typical daily activities performed by women in rural India. Design: A cross-sectional study covering 26 different activities was done by indirect calorimetry using the Oxylog ${ }^{\mathrm{TM}}$ instrument (Morgan).

Settings: Villages about 30-40 km from Pune city, Maharashtra, India.

Subjects: Energy costs were measured on 22 rural Indian women aged 18-45 years.

Results: Irrespective of whether an activity was domestic or farming, energy cost was lower when performed in sitting position (cleaning grains $5.24 \mathrm{~kJ} \mathrm{~min}^{-1}$, plucking leafy vegetables $5.76 \mathrm{~kJ} \mathrm{~min}^{-1}$ ) and increased considerably with the extent of muscular movement (carrying two water containers $14.77 \mathrm{~kJ} \mathrm{~min}^{-1}$, chopping firewood $14.5 \mathrm{~kJ} \mathrm{~min}^{-1}$ ), indicating the importance of the postural details of the activity. Physical activity ratio computed using the Food and Agriculture Organization/World Health Organization/United Nations University equation $\left(\mathrm{PAR}_{\mathrm{w}}\right)$ was lower for all activities compared with that $\left(\mathrm{PAR}_{\mathrm{m}}\right)$ based on measured basal metabolic rate, indicating the need for a population-specific equation. Furthermore, PAR $_{\mathrm{w}}$ identified more activities as belonging to the 'very light' category (nine out of 26 activities), in contrast to the perception of rural women which was supported with empirical evidence. Estimated daily energy expenditure of the women was $7.69 \pm 0.63 \mathrm{MJ}(1837 \pm 150 \mathrm{kcal})$ and identified their daily activity pattern as 'moderate' based on $\mathrm{PAL}_{\mathrm{w}}(1.65 \pm 0.16)$ while $\mathrm{PAL}_{\mathrm{m}}$ (2.04 \pm 0.18$)$ identified it as 'heavy'.

Conclusions: Our results highlight the importance of qualitative descriptions of the various activities. The energy costs for several daily activities reported in this study could potentially be used for estimating daily energy expenditure of women from similar rural settings.
\end{abstract}

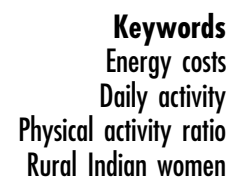

Keywords

Energy costs

Physical activity ratio

Rural Indian women
Discrepancies between measured intakes and estimates of energy expenditure are commonly reported for marginally malnourished populations in the developing world. Very low levels of energy intake, which appear to be incompatible with the levels of obligatory physical activity associated with rural farming life, are often explained by energy sparing through a decrease in basal metabolic rate $(\mathrm{BMR})^{1,2}$, a decrease in discretional activities $^{3-5}$ or a decrease in the energy cost of activities ${ }^{6}$. However, in the real-life situation with marginal but sustained energy stress, the reduction in BMR is believed to be negligible ${ }^{7}$. Although reduction in physical activity appears to be an easy strategy to combat energy stress, it is not always possible in subsistence farming communities $^{8}$. In fact, the change in physical activity that occurs is due only to the seasonality in agricultural tasks 9 . Thus, observed seasonal variation in body weight or body $\mathrm{fat}^{10,11}$ in such communities reflects a way of coping with their marginal energy stress ${ }^{12}$. With little scope for reduction in activity, the decrease in energy cost of activities is therefore believed to be the logical and feasible way of coping with energy stress at no or a minimum cost $^{7}$.

Evidence suggests that even among individuals of similar age and sex, physical activity is usually the most important factor causing variations in energy expenditure $^{13}$. Studies reporting energy expenditure on various activities for Indian adults are scarce ${ }^{14,15}$ and those available are on women engaged in activities other than farming ${ }^{16,17}$. Rural women in India are engaged in domestic chores and also contribute substantially in farming activities. Yet, their reported ${ }^{18,19}$ energy intakes are very low. Measuring the energy costs of various activities among rural Indian women would therefore contribute to the current interest in understanding mechanisms of adaptation to long-term low energy intakes. In the present work we measured the energy cost of typical daily activities that women from farming 
communities perform in rural Maharashtra, India, computed their physical activity ratios to assess their energy requirement and compared it with their estimated daily energy expenditure.

\section{Materials and methods}

\section{Rural community}

The subjects were selected from villages about $30-40 \mathrm{~km}$ away from Pune city, where other community nutrition projects of the department were being implemented. A total of 22 women (aged 18-45 years), who volunteered themselves for wearing a mask for the measurements, were considered for measuring the energy costs of various activities pertaining to a rural lifestyle. Agriculture is the main occupation in this area and the majority of women have to participate in several farming activities like weeding, planting onion seedlings, harvesting the Bengal gram plants, cutting fodder, de-shelling groundnuts, etc. These activities are tedious and require long hours of sitting or bending.

\section{Daily activities of rural women}

In India, domestic activities consume a considerable amount of women's time and energy, especially in rural areas as electrical appliances are not yet in common use. Domestic work mainly involves cooking, washing utensils and clothes, and sweeping the floor. Food is cooked on a traditional chulha (earthen stove) that uses firewood as fuel. The morning activities start with chopping of the stored firewood. Cooking includes activities like making dough and rolling roties, cleaning and cutting vegetables, and grinding spices for gravy. Utensils are washed two or three times a day. The activity of washing clothes is generally done at the well. In some cases women have to go to the river to wash clothes and therefore they have to carry the burden both ways. They have to fetch water daily from a well or hand pump usually situated about $1 \mathrm{~km}$ away from house. They carry at least two water containers (total weight of about $25 \mathrm{~kg}$ ) on their head at each trip and make a couple of trips to satisfy the water needs of the family for the day. Women have to sweep the house and courtyard as well as the animal shed every day. Some women also help in milking the cows/buffaloes. Prolonged breast-feeding being a common practice, young mothers spend considerable energy in breastfeeding the child several times a day. Rural women have hardly any recreational activities. During their spare time, visiting a neighbour's house to chat or drink tea is a common practice.

In addition to their daily activities rural women have to gather firewood at least twice a week. The dirt flooring inside the house as well as in the courtyard is levelled once a week by putting down coats of cow/buffalo dung. Another important weekly activity is cleaning grains, which involves winnowing and removing non-edible items from the grains.

We measured the energy costs for resting (i.e. resting metabolic rate; RMR), three standard activities (sitting, standing and walking) and 22 different daily activities that were commonly performed by rural women. A description of these activities is given in the Appendix. The energy cost of each activity was measured in duplicate on three or four women.

\section{Antbropometry}

Before measuring energy costs, anthropometric measurements were recorded on each subject. Body weight was measured with the women wearing casual clothes, in their house, using an electronic weighing balance (ATCO) with accuracy of $20 \mathrm{~g}$. Height was measured on barefoot women with a folding stadiometer (UNA) and recorded to the nearest $1 \mathrm{~mm}$. Measurements were recorded by trained researchers and care was taken to minimise personal errors. Body fat was estimated using a body fat analyser (HBF 300; OMRON Corporation) which works on the principle of bioelectrical impedance.

\section{Measurement of energy costs}

Energy costs were measured by indirect calorimetry using the Oxylog ${ }^{\mathrm{TM}}$ (Morgan) portable oxygen consumption meter. It was calibrated before taking measurements using oxygen-free nitrogen. The equipment had an in-built facility for adjusting barometric pressure to $760 \mathrm{~mm}$. The least count of the equipment is 0.1 litre $\mathrm{O}_{2}$.

The women were familiarised with the Oxylog and the procedures involved before starting the measurements, which were recorded at home or in the field. The Oxylog was strapped to the subject's back or set beside her for sedentary measurements. The face mask was put on and the actual measurement of oxygen consumption was started only after ensuring that the subject was comfortable with the face mask. This often took few minutes after which the measurement was recorded for the duration of $6 \mathrm{~min}$. A duplicate reading was taken after a gap of $10 \mathrm{~min}$. The average of both readings was used for the analysis.

For measurement of RMR subjects were informed on the previous day and were visited early in the morning next day before they started their routine work. Standard procedures described earlier ${ }^{20}$ were followed for the measurement and energy costs were obtained $\left(\mathrm{kJ} \mathrm{min}^{-1}\right)$. The study was approved by the Research Advisory Committee of Agharkar Research Institute and received institutional funding.

\section{Pbysical activity ratio}

The physical activity ratio (PAR) is defined as the energy cost of the activity divided by either the measured or the 
predicted basal metabolic rate (BMR). Thus, for each activity, $\mathrm{PAR}_{\mathrm{W}}$ was computed using BMR predicted for individual women from the Food and Agriculture Organization/World Health Organization/United Nations University (FAO/WHO/UNU) equation (1985) ${ }^{21}$, while $\mathrm{PAR}_{\mathrm{m}}$ was computed using BMR estimated from measured values of RMR (as RMR $\times 0.8$ ). For categorising the physical activity pattern and lifestyle of the rural women, the physical activity level (PAL), as an index of total energy expenditure adjusted for BMR, was also calculated.

\section{Daily energy expenditure}

The values of energy costs measured for various daily activities were used to estimate the daily energy expenditure of the rural women. For this purpose, we made use of observational data from an activity diary maintained on rural women $(n=16)$ from the same villages but collected under another departmental project. These data were collected on individual women who were followed throughout the day from waking up (07.00 hours) until bedtime (21.00 hours). The data revealed the time spent by rural women in various daily activities and allowed us to estimate their daily energy expenditure using the energy costs measured in the present study. The energy costs during sleep and nap were obtained by applying a $15 \%$ reduction $^{8}$ to the value obtained for lying (i.e. RMR, which was measured in the morning). Leisure time spent in some activities like sitting, drinking tea, chatting, eating meals, etc. involved little use of arms and was assumed to be equivalent to sitting inactive ${ }^{8}$. The energy costs for activities including some personal activities like bathing, which were difficult to measure, were estimated by assuming average cost of $5.86 \mathrm{~kJ} \mathrm{~min}^{-1}\left(1.4 \mathrm{kcal} \mathrm{min}^{-1}\right)$.

\section{Statistical methods}

Data are given as mean \pm standard deviation energy costs expressed as $\mathrm{kJ} \mathrm{min}^{-1}$ and PAR. The $t$-test was used for comparing the difference between measured and reported energy costs and PARs for different activities.

\section{Results}

The rural women were thin (mean body weight $47.5 \pm$ $6.4 \mathrm{~kg}$ ) and short (mean height $151.8 \pm 3.5 \mathrm{~cm}$ ). The average body mass index (BMI) was low (20.6 \pm 2.5 $\mathrm{kg} \mathrm{m}^{-2}$ ) and the percentage of undernourished women (i.e. with $\mathrm{BMI}<18.5 \mathrm{~kg} \mathrm{~m}^{-2}$ ) was $14.0 \%$.

Estimates from the observer-maintained activity diary showed that their mean active time spent in various daily activities (Table 1) was $947 \pm 48 \mathrm{~min}$, while the average time spent in sleeping was $469 \pm 50 \mathrm{~min}$, leaving only $24 \pm 16$ min unaccounted for. It can be seen that the major part of their active time was spent in domestic activity (38.0\%) followed by farming activity (33.6\%). Almost all women had to do domestic work consisting of cooking,

Table 1 Time spent in daily activities by rural Indian women

\begin{tabular}{|c|c|c|c|c|}
\hline \multirow{2}{*}{$\begin{array}{l}\text { Activity } \\
\text { group }\end{array}$} & \multirow[b]{2}{*}{ Activities } & \multirow[b]{2}{*}{$N$} & \multicolumn{2}{|c|}{ Time spent } \\
\hline & & & Total min & $\%$ of active time* \\
\hline \multirow[t]{2}{*}{ Resting } & Sleep & 16 & $468.8 \pm 51.2$ & - \\
\hline & Nap & 8 & $118.2 \pm 30.2$ & \\
\hline \multirow[t]{3}{*}{ Recreation } & & 16 & $104.8 \pm 63.6$ & $11.0 \pm 6.7$ \\
\hline & Watching television & 7 & $81.4 \pm 37.6$ & \\
\hline & Chatting & 16 & $104.8 \pm 63.6$ & \\
\hline \multirow[t]{16}{*}{ Domestic } & & 16 & $360.3 \pm 80.4$ & $38.0 \pm 8.1$ \\
\hline & Cooking & 16 & $172.3 \pm 69.9$ & \\
\hline & Chopping firewood & 6 & $15.3 \pm 6.1$ & \\
\hline & Making roties & 14 & $74.3 \pm 37.6$ & \\
\hline & Other cooking & 16 & $101.6 \pm 46.5$ & \\
\hline & Cleaning & 16 & $133.1 \pm 38.8$ & \\
\hline & Utensils & 16 & $45.1 \pm 21.0$ & \\
\hline & Clothes (indoor) & 15 & $55.8 \pm 18.4$ & \\
\hline & Sweeping the house & 15 & $38.1 \pm 21.0$ & \\
\hline & $\begin{array}{l}\text { Fetching water (from either well or bore well) } \\
\text { \& carrying to home }\end{array}$ & 14 & $62.7 \pm 39.0$ & \\
\hline & Allied activities & 13 & $113.9 \pm 80.0$ & $12.0 \pm 8.5$ \\
\hline & Cleaning grains (winnowing) & 6 & $26.5 \pm 23.3$ & \\
\hline & Cleaning animal shed & 7 & $53.7 \pm 37.5$ & \\
\hline & Using sewing machine & 2 & $179.0 \pm 90.0$ & \\
\hline & Breast-feeding & 6 & $42.3 \pm 17.9$ & \\
\hline & Child care & 8 & $41.8 \pm 34.7$ & \\
\hline Farming & $\begin{array}{l}\text { Weeding, plucking of plants \& } \\
\text { de-shelling groundnuts }\end{array}$ & 5 & $314 \pm 108.7$ & $33.6 \pm 12.1$ \\
\hline Other & $\begin{array}{l}\text { Personal care such as bathing, } \\
\text { refreshing, eating, etc. }\end{array}$ & 16 & $106.3 \pm 26.0$ & $11.2 \pm 2.6$ \\
\hline
\end{tabular}

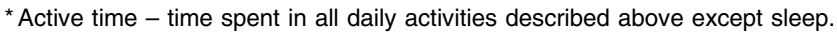


Table 2 Energy costs, in $\mathrm{kJ} \mathrm{min}^{-1}$, of resting, standard, domestic and farming activities measured on rural Indian women

\begin{tabular}{|c|c|c|}
\hline $\begin{array}{l}\text { Activity } \\
\text { group }\end{array}$ & Details of the activity & $\begin{array}{l}\text { Energy cost } \\
\left(\mathrm{kJ} \mathrm{min}^{-1}\right)\end{array}$ \\
\hline \multirow[t]{2}{*}{ Resting } & Lying (RMR) & $3.02 \pm 0.22$ \\
\hline & Watching television & $3.96 \pm 0.08$ \\
\hline \multirow[t]{3}{*}{ Standard } & Sitting* & $3.66 \pm 0.06$ \\
\hline & Standing & $4.10 \pm 0.21$ \\
\hline & Walking & $8.49 \pm 0.46$ \\
\hline \multicolumn{3}{|l|}{ Domestic } \\
\hline \multirow[t]{3}{*}{ Cooking } & Making roties & $6.22 \pm 0.16$ \\
\hline & Making vegetables & $6.45 \pm 0.75$ \\
\hline & $\begin{array}{l}\text { Grinding spices using mortar \& } \\
\text { pestle }\end{array}$ & $8.20 \pm 0.14$ \\
\hline \multirow[t]{5}{*}{ Cleaning } & Utensils & $8.03 \pm 0.39$ \\
\hline & Clothes (indoor) & $11.05 \pm 0.30$ \\
\hline & Clothes (at the well) & $13.26 \pm 1.14$ \\
\hline & Sweeping the floor & $5.70 \pm 0.22$ \\
\hline & Setting dirt floor with cow dung & $6.81 \pm 0.78$ \\
\hline \multirow[t]{2}{*}{$\begin{array}{l}\text { Fetching } \\
\text { water }\end{array}$} & $\begin{array}{l}\text { From draw well } \\
\text { Using hand pump }\end{array}$ & $\begin{array}{l}8.73 \pm 0.49 \\
8.14 \pm 0.82\end{array}$ \\
\hline & $\begin{array}{l}\text { Carrying two water containers on } \\
\text { head }\end{array}$ & $14.77 \pm 0.66$ \\
\hline \multirow[t]{4}{*}{$\begin{array}{l}\text { Allied } \\
\text { activities }\end{array}$} & $\begin{array}{l}\text { Cleaning grains } \\
\text { Breast-feeding }\end{array}$ & $\begin{array}{l}5.24 \pm 0.14 \\
4.94 \pm 0.36\end{array}$ \\
\hline & Cleaning animal shed & $7.62 \pm 0.22$ \\
\hline & $\begin{array}{l}\text { Stitching clothes on sewing } \\
\text { machine }\end{array}$ & $8.14 \pm 0.72$ \\
\hline & Grinding cereals using millstone & $12.80 \pm 0.64$ \\
\hline \multirow[t]{5}{*}{ Farming } & Chopping firewood & $14.50 \pm 0.87$ \\
\hline & Walking with load (firewood) & $9.54 \pm 0.44$ \\
\hline & Weeding & $9.95 \pm 1.03$ \\
\hline & Plucking leafy vegetables & $5.76 \pm 0.57$ \\
\hline & De-shelling groundnuts & $5.06 \pm 0.28$ \\
\hline
\end{tabular}

RMR - resting metabolic rate.

${ }^{*}$ Readings were on four subjects while all other activities were measured on three subjects.

cleaning (clothes, utensils and house) and fetching water, which contributed $18.3 \%, 14.0 \%$ and $6.5 \%$ of the active time, respectively. Apart from these daily activities, $12.0 \%$ of the women's time was spent in allied activities like child care, cleaning of grains and cleaning of animal sheds, while $11.0 \%$ of their time was spent in recreational activities like watching television and chatting.

Energy cost was therefore measured for these major daily activities along with RMR and for three 'standard' activities (sitting, standing and walking). The energy cost for these standard activities varied from 3.66 to $8.49 \mathrm{~kJ} \mathrm{~min}^{-1}$ and increased with change in posture from sitting to walking (Table 2). Energy costs were lowest for activities in the 'Resting' category, which included RMR $\left(3.02 \mathrm{~kJ} \mathrm{~min}^{-1}\right)$ and watching television $\left(3.96 \mathrm{~kJ} \mathrm{~min}^{-1}\right)$.

In the 'Domestic' category, energy costs for activities mostly done in sitting posture were lower (cleaning grains $5.24 \mathrm{~kJ} \mathrm{~min}^{-1}$, making roties $6.22 \mathrm{~kJ} \mathrm{~min}^{-1}$, cooking vegetables $6.45 \mathrm{~kJ} \mathrm{~min}^{-1}$, sweeping the floor $5.7 \mathrm{~kJ} \mathrm{~min}^{-1}$, setting the dirt floor with cow dung $6.81 \mathrm{~kJ} \mathrm{~min}^{-1}$ ). However, activities requiring muscular movement in the sitting position needed slightly higher energy (grinding spices with mortar and pestle $8.20 \mathrm{~kJ} \mathrm{~min}^{-1}$, cleaning utensils $8.03 \mathrm{~kJ} \mathrm{~min}^{-1}$, stitching clothes on sewing machine $8.14 \mathrm{~kJ} \mathrm{~min}^{-1}$ ). This was also true for activities done in bending position (drawing water from well $8.73 \mathrm{~kJ} \mathrm{~min}^{-1}$, cleaning animal shed $7.62 \mathrm{~kJ} \mathrm{~min}^{-1}$ ). However, the most tiring activities were washing clothes at the well $\left(13.26 \mathrm{~kJ} \mathrm{~min}^{-1}\right)$, carrying two water containers on the head $\left(14.77 \mathrm{~kJ} \mathrm{~min}^{-1}\right)$ and grinding cereals on a millstone $\left(12.80 \mathrm{~kJ} \mathrm{~min}^{-1}\right)$. It can be observed that carrying two water containers on the head required more energy than actually drawing water from the well or using a hand pump.

The activities in the 'Farming' category also showed a similar trend, as activities in sitting position had lower energy costs (plucking leafy vegetables $5.76 \mathrm{~kJ} \mathrm{~min}^{-1}$, de-shelling groundnuts $5.06 \mathrm{~kJ} \mathrm{~min}^{-1}$ ) while those performed in bending, standing or walking position and involving movement had considerably higher energy costs (weeding $9.95 \mathrm{~kJ} \mathrm{~min}^{-1}$, walking with load of firewood $9.54 \mathrm{~kJ} \mathrm{~min}^{-1}$ ). It is worthwhile to note that 'weeding' is a routine, tedious activity that is labelled women's work in rural farming communities in India. However, the highest energy cost was observed for the activity of chopping firewood $\left(14.50 \mathrm{~kJ} \mathrm{~min}^{-1}\right)$.

Energy expenditure expressed in terms of BMR factors $\left(\mathrm{PAR}_{\mathrm{w}}\right.$ and $\mathrm{PAR}_{\mathrm{m}}$ ) was compared for the various activities (Table 3). It can be seen that $\mathrm{PAR}_{\mathrm{m}}$ values were higher than $\mathrm{PAR}_{\mathrm{w}}$ for almost all activities. This indicates that measured $\mathrm{BMR} / \mathrm{RMR}$ values for populations in developing countries are lower than those estimated by the $\mathrm{FAO} / \mathrm{WHO} / \mathrm{UNU}^{21}$ equation, as reported earlier by other researchers ${ }^{22}$. However, the differences between the two increased as the level of activity increased. Differences were smaller (of the order of 0.5 ) for activities like lying, sitting, standing and watching television. For activities such as making roties and vegetables, sweeping the floor, cleaning the animal shed and fetching water, the difference was in the range of 0.5 to 1.0 , and in the case of activities where rigorous movements were involved, the differences were above 1.0 with the highest value of 2.0 for chopping firewood. Comparison of $\mathrm{PAR}_{\mathrm{m}}$ values with $\mathrm{BMR}$ factors given by $\mathrm{FAO} / \mathrm{WHO} / \mathrm{UNU}^{21}$ also showed smaller differences for light activities and larger differences for heavy activities, despite the fact that these BMR factors given for various activities include the cost of minor movement, muscle tone and specific metabolic response to food. The differences may arise in part because of the lack of uniformity in defining exactly the way in which an activity is performed. Alternatively, these observations indicate the need for population-specific equations for estimation of RMR/BMR, especially for people from developing countries.

The differences consequently affect the classification of activities (Table 4). In general, based on $\mathrm{PAR}_{\mathrm{w}}$, more activities (nine out of 26) are identified as 'very light' $(\mathrm{PAR}<1.7)$ while when based on $\mathrm{PAR}_{\mathrm{m}}$ more activities (14 out of 26) are identified as 'heavy' (PAR $>2.8$ ). In the 
Table 3 Energy costs, in terms of physical activity ratio (PAR), for resting, standard, doenstic and farming activities measured on rural Indian women

\begin{tabular}{|c|c|c|c|c|}
\hline Activity group & Details of the activity & $\mathrm{PAR}_{\mathrm{w}}{ }^{*}$ & $\mathrm{PAR}_{\mathrm{m}} \dagger$ & BMR factors $\ddagger$ \\
\hline \multirow[t]{2}{*}{ Resting } & Lying (RMR) & $0.84 \pm 0.04$ & $1.20 \pm 0.09$ & 1.2 \\
\hline & Watching television & $1.10 \pm 0.04$ & $1.64 \pm 0.12$ & - \\
\hline \multirow[t]{3}{*}{ Standard } & Sitting & $1.01 \pm 0.06$ & $1.47 \pm 0.07$ & 1.2 \\
\hline & Standing & $1.15 \pm 0.03$ & $1.71 \pm 0.06$ & 1.5 \\
\hline & Walking & $2.35 \pm 0.08$ & $3.52 \pm 0.19$ & 3.4 \\
\hline \multicolumn{5}{|l|}{ Domestic } \\
\hline \multirow[t]{3}{*}{ Cooking } & Making roties & $1.74 \pm 0.04$ & $2.65 \pm 0.08$ & 2.1 \\
\hline & Making vegetables & $1.79 \pm 0.16$ & $2.66 \pm 0.12$ & 1.8 \\
\hline & Grinding spices using mortar \& pestle & $2.32 \pm 0.09$ & $3.31 \pm 0.15$ & - \\
\hline \multirow[t]{5}{*}{ Cleaning } & Utensils & $2.17 \pm 0.08$ & $3.21 \pm 0.25$ & 1.7 \\
\hline & Clothes (indoor) & $2.96 \pm 0.09$ & $4.36 \pm 0.35$ & 3.0 \\
\hline & Clothes (at the well) & $3.77 \pm 0.32$ & $5.49 \pm 0.47$ & - \\
\hline & Sweeping the floor & $1.58 \pm 0.04$ & $2.36 \pm 0.14$ & 2.2 \\
\hline & Setting dirt floor with cow dung & $1.85 \pm 0.13$ & $2.67 \pm 0.06$ & - \\
\hline \multirow[t]{3}{*}{ Fetching water } & From draw well & $2.71 \pm 0.27$ & $3.61 \pm 0.20$ & 4.1 \\
\hline & Using hand pump & $2.48 \pm 0.70$ & $3.37 \pm 0.34$ & - \\
\hline & Carrying two water containers on head & $4.59 \pm 0.41$ & $6.11 \pm 0.27$ & 4.0 \\
\hline \multirow[t]{5}{*}{ Allied activities } & Cleaning grains & $1.45 \pm 0.04$ & $2.17 \pm 0.10$ & 1.7 \\
\hline & Breast-feeding & $1.43 \pm 0.03$ & $2.04 \pm 0.15$ & - \\
\hline & Cleaning animal shed & $2.18 \pm 0.06$ & $3.15 \pm 0.09$ & - \\
\hline & Stitching clothes on sewing machine & $2.21 \pm 0.22$ & $3.37 \pm 0.30$ & - \\
\hline & Grinding cereals using millstone & $3.39 \pm 0.04$ & $4.94 \pm 0.14$ & 3.8 \\
\hline \multirow[t]{5}{*}{ Farming } & Chopping firewood & $4.03 \pm 0.14$ & $6.01 \pm 0.07$ & 4.3 \\
\hline & Walking with load (firewood) & $2.64 \pm 0.05$ & $3.95 \pm 0.10$ & - \\
\hline & Weeding & $2.69 \pm 0.17$ & $3.85 \pm 0.03$ & 2.9 \\
\hline & Plucking leafy vegetables & $1.56 \pm 0.09$ & $2.22 \pm 0.05$ & - \\
\hline & De-shelling groundnuts & $1.40 \pm 0.04$ & $2.09 \pm 0.04$ & 1.9 \\
\hline
\end{tabular}

BMR - basal metabolic rate; RMR - resting metabolic rate.

${ }^{*}$ Based on BMR estimates using the Food and Agriculture Organization/World Health Organization/United Nations University (FAO/WHO/UNU) prediction equation (1985) ${ }^{21}$.

+ Based on BMR estimates using assumptions $(B M R=R M R \times 0.8)$.

‡FAO/WHO/UNU $(1985)^{21}$.

'very light' category concordance was seen for three activities (lying, watching television and sitting) while in the 'heavy' category five activities showed concordance. On the other hand, there was no concordance for the 'light' and 'moderate' categories, which comprised the activities actually done when the women were active during the daytime (cooking, cleaning of utensils, grains and animal shed, weeding, etc.).

Using the data from the activity diary and the mean values of energy costs measured in this study, the daily energy expenditure was estimated. The daily energy expenditure of these rural women was thus $7.69 \pm 0.63 \mathrm{MJ}$ $(1837 \pm 150 \mathrm{kcal})$. The estimate of $\mathrm{PAL}_{\mathrm{w}}$ based on BMR using the $\mathrm{FAO} / \mathrm{WHO} / \mathrm{UNU}$ prediction equation was $1.65 \pm 0.16$, which indicates that the overall activity pattern of rural women can be considered 'moderate'.

\section{Discussion}

Studies measuring energy intake and expenditure in malnourished populations in developing countries indicate that mean energy expenditure exceeds mean energy intake, more so in women who are often involved in domestic as well as farming activities ${ }^{23-26}$. These data emphasise the need for estimating the PAL for women in such communities and comparing it with the estimates given by $\mathrm{FAO} / \mathrm{WHO} / \mathrm{UNU}^{21}$, as physical activity is believed to be the possible mode for energy homeostasis ${ }^{7}$. However, very few data are available on energy expenditure in various activities in rural communities of developing countries. The present study reports, for the first time, the energy costs and PAR values for a large number of activities which are typical of the work pattern and PAL of Indian rural women.

In rural communities, ignorance, non-cooperation, cultural unacceptability and the disruptive nature of measurements to the rural lifestyle all make it difficult to include a large number of subjects. Some earlier studies also measured energy costs of activities on small numbers of subjects ${ }^{27-29}$. However the importance of such data, although on smaller numbers of subjects, needs to be appreciated in view of the scarcity of data on energy expenditure. In our study we tried to cover most of the typical daily activities that a rural woman performs. Therefore, this information could be useful in estimating energy expenditures close to the reality for rural women in India.

Mean time spent $(314 \pm 109 \mathrm{~min})$ in farming activities in our study was comparable to the reported value (273 min) for female farmers from Upper Volta ${ }^{8}$. On the other hand, time spent in domestic work $(579 \pm 135 \mathrm{~min})$ was considerably more than that reported in other studies and thus effectively reduced the resting time of the Indian 
women $(633 \pm 113 \mathrm{~min})$, which was less than that reported $(758 \mathrm{~min}$ and $977 \mathrm{~min}$ ) for women from Upper Volta $^{8,23}$.

The energy costs ( $\mathrm{kJ}$ ( $\mathrm{kg}$ body weight) ${ }^{-1} \mathrm{~h}^{-1}$ ) of various activities measured in this study were generally lower than reported ones ${ }^{8,28,30}$, showing larger differences for light activities (e.g. activities related to cooking and washing or cleaning) than for strenuous activities (e.g. carrying water, chopping firewood). Although such differences are often attributed to the inability in standardising activities across different populations ${ }^{28}$, the fact that they were significantly lower $(P<0.01)$ for all three 'standard' activities (Table 5) indicates the importance of racial differences or differences in body composition in different populations ${ }^{31}$. However, it may be worthwhile to note further that, after adjusting for fat-free mass, these energy costs were significantly lower even when compared with urban women from Pune ${ }^{20}$ for resting (3.06 \pm 0.38 vs. $\left.3.72 \pm 0.16 \mathrm{~kJ} \mathrm{~min}^{-1}, P<0.000\right)$, sitting $\left(3.68 \pm 0.79\right.$ vs. $\left.4.36 \pm 0.31 \mathrm{~kJ} \mathrm{~min}^{-1}, \quad P=0.002\right)$ and standing ( $4.19 \pm 0.67$ vs. $4.71 \pm 0.31 \mathrm{~kJ} \mathrm{~min}^{-1}, P=0.01$ ). These observations therefore call for further understanding of the mechanisms of energy sparing in undernourished populations.

Some studies have reported reduction in discretionary activities as a means of coping with energy stress ${ }^{32,33}$. But in the case of rural Indian women, this possibility is rare and their daily activity pattern becomes obligatory, as it is associated with basic needs for survival. In view of this, the low values of energy costs of various activities, and especially that of RMR, observed for rural Indian women assume significance and may indicate an adaptation to long-term marginal energy stress.

Our observation that $\mathrm{PAR}_{\mathrm{m}}$ values were higher than $\mathrm{PAR}_{\mathrm{w}}$ confirms the findings from previous reports that use of the $\mathrm{FAO} / \mathrm{WHO} / \mathrm{UNU}^{21}$ equation may overestimate BMR in the case of undernourished populations ${ }^{34,35}$. Furthermore, it was shown to lead to considerable misclassification of activities, as $\mathrm{PAR}_{\mathrm{w}}$ identifies more activities as belonging in the very light category and fewer activities in the heavy category. For example, the activity of fetching water is classified as a moderate activity by $\mathrm{PAR}_{\mathrm{w}}$ but as a heavy activity by $\mathrm{PAR}_{\mathrm{m}}$. In contrast, rural Indian women perceived this activity as strenuous activity, which was strengthened by its negative association with birth $\operatorname{size}^{36}$. A study on rural women from Karnataka ${ }^{37}$ also highlighted the high energy costs of fuel, fodder and water collection. Therefore, the qualitative aspects of activity level are equally as important as the quantitative aspects, more so in the case of field studies where actual measurements of energy costs are extremely difficult.

The estimate of daily energy expenditure of $1837 \pm 150 \mathrm{kcal}$, based on the observer-maintained diary for rural women in Maharashtra, was comparable to that observed for rural Punjabi women $(2048 \pm 37 \mathrm{kcal})^{19}$, 
Table 5 Comparison of energy costs of resting and standard activities for rural women with reported values

\begin{tabular}{|c|c|c|c|}
\hline Activity & Reference & Population (no. of subjects) & Energy cost $\left(\mathrm{kJ} \mathrm{kg}^{-1} \mathrm{~h}^{-1}\right)$ \\
\hline \multicolumn{4}{|l|}{ Resting } \\
\hline \multirow[t]{6}{*}{ RMR } & Present study & India (3) & $3.77 \pm 0.13$ \\
\hline & Lawrence et al. $(1985)^{30}$ & Africa (25) & $5.53 \pm 0.63^{\star \star}$ \\
\hline & Thomas (1973)† & Peru (8) & $5.27^{\star \star}$ \\
\hline & Geissler et al. $(1981)^{27}$ & Iran (17) & $5.57 \pm 0.92^{\star *}$ \\
\hline & Bleiberg et al. $(1980)^{8}$ & Upper Volta (29) & $5.65 \pm 1.00^{\star \star}$ \\
\hline & Yamauchi \& Ohtsuka $(2000)^{29}$ & Papua New Guinea (8) & $6.07 \pm 0.46^{\star \star}$ \\
\hline \multicolumn{4}{|c|}{ 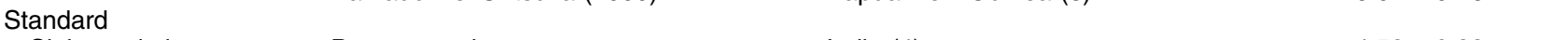 } \\
\hline \multirow[t]{6}{*}{ Sitting quietly } & Present study & India (4) & $4.58 \pm 0.33$ \\
\hline & Geissler et al. $(1981)^{27}$ & Iran (27) & $5.78 \pm 0.88^{\star \star}$ \\
\hline & Yuchingtat et al. (1995) ${ }^{26}$ & Philippines (8) & $5.78^{* *}$ \\
\hline & Lawrence et al. $(1985)^{30}$ & Africa (174) & $5.78 \pm 1.00^{\star}$ \\
\hline & Bleiberg et al. $(1980)^{8^{\prime}}$ & Upper Volta (27) & $5.90 \pm 1.09^{\star \star}$ \\
\hline & Yamauchi \& Ohtsuka $(2000)^{29}$ & Papua New Guinea (8) & $6.16 \pm 0.31^{\star *}$ \\
\hline \multirow[t]{7}{*}{ Standing } & Present study & India (3) & $5.18 \pm 0.36$ \\
\hline & Lawrence et al. $(1985)^{30}$ & Africa (109) & $5.94 \pm 1.09$ \\
\hline & Thomas (1973)† & Peru (8) & $5.78^{\star \star}$ \\
\hline & Yuchingtat et al. $(1995)^{26}$ & Philippine (8) & $7.53^{\star *}$ \\
\hline & Geissler et al. $(1981)^{27}$ & Iran (18) & $6.2 \pm 1.05^{\star \star}$ \\
\hline & Bleiberg et al. $(1980)^{8}$ & Upper Volta (27) & $6.15 \pm 1.13^{\star \star}$ \\
\hline & Yamauchi \& Ohtsuka (2000) $)^{29}$ & Papua New Guinea (8) & $7.51 \pm 0.4^{* \star}$ \\
\hline
\end{tabular}

RMR - resting metabolic rate.

${ }^{*} P<0.05$ for comparison with the estimates in the present study.

${ }^{\star \star} P<0.01$ for comparison with the estimates in the present study.

+Values taken from Torun et al. $(1982)^{28}$.

Iranian women $(1885 \pm 215 \mathrm{kcal})^{27}$ and British women $(1866 \pm 311 \mathrm{kcal}, 7.69 \pm 0.63 \mathrm{MJ})^{38}$. $\mathrm{PAL}_{\mathrm{w}}$ computed using $\mathrm{BMR}$ estimated from the $\mathrm{FAO} / \mathrm{WHO} / \mathrm{UNU}^{21}$ equation was $1.65 \pm 0.16$, indicating a 'moderate' activity pattern of rural women, while based on our earlier reported ${ }^{20}$ equation for estimating RMR for Indian adults $\mathrm{PAL}_{\mathrm{m}}$ was $2.04 \pm 0.18$, identifying appropriately the activity pattern of rural women as 'heavy'. The findings therefore highlight the need for population-specific equations for estimation of RMR/BMR, especially among people from developing countries.

In view of the paucity of such data due to the enormous difficulties faced by researchers in measuring actual energy costs, the findings of our study assume importance. Our data on energy costs for several daily activities could be used in combination with activity diaries to estimate the daily energy expenditure of women in the rest of rural India, as rural lifestyles in different states of India are reasonably similar.

\section{Conclusions}

In conclusion, using $\mathrm{FAO} / \mathrm{WHO} / \mathrm{UNU}^{21}$ estimates of BMR, most daily activities of rural women could be classified as 'very light' and 'light' on the basis of PAR while their overall daily activity pattern is identified as 'moderate' on the basis of $\mathrm{PAL}_{\mathrm{w}}$. In contrast, low adult body weights of individuals from developing countries is perhaps the reflection of long-term energy stress, as they are engaged in energy-demanding activities with relatively low levels of dietary intake as reported by many studies ${ }^{39-41}$. Our study thus highlights two important issues in the context of estimating energy expenditure in field studies: the need for population-specific equations for estimating BMR and the importance of data on qualitative descriptions of various activities. This will facilitate sound comparisons of energy expenditure patterns in different populations.

\section{Acknowledgements}

Sources of funding: This study was supported by a grant from Agharkar Research Institute (ARI), Pune, India.

Conflict of interest declaration: The authors declare that there is no conflict of interest.

Authorship responsibilities: S.R., Principal Investigator of the study, was responsible for developing and writing the manuscript, while M.G. and A.K. were responsible for data collection and analysis.

Acknowledgements: The authors are grateful to Dr VS Rao, Director ARI, for encouragement and providing the facilities to carry out this work in the Institute. The authors also express their appreciation to the village women for their cooperation throughout the study.

\section{References}

1 Durnin JVGA, Drummond S, Satyanarayana K. A collaborative EEC study on seasonality and marginal nutrition. The Glasgow-Hyderabad (S. India) Study. European Journal of Clinical Nutrition 1990; 44(Suppl. 1): 19-29. 
2 Poppitt SD, Prentice AM, Jequier E, Schutz Y, Whitehead RG. Evidence of energy sparing in Gambian women during pregnancy: a longitudinal study using whole-body calorimetry. American Journal of Clinical Nutrition 1993; 57: 353-64.

3 Pastore G, Branca F, Demissie T, Ferro-Luzzi A. Seasonal energy stress in an Ethiopian rural community: an analysis of the impact at the household level. European Journal of Clinical Nutrition 1993; 47: 851-62.

4 Durnin JVGA. Energy balance in man with particular reference to low intakes. Bibliotheca Nutritio et Dieta 1979; 27: 1-10

5 Edmundson WC, Sukhatme PV. Energy intake and human productivity. In: Edmundson WC, Sukhatme PV, Edmundson SA, eds. Diet, Disease and Development. New Delhi: Macmillan India Ltd, 1992; 56-83.

6 Shetty PS. Adaptive changes in basal metabolic rate and lean body mass in chronic undernutrition. Human Nutrition: Clinical Nutrition 1984; 38C: 443-51.

7 Ferro-Luzzi A. Social and public health issues in adaptation to low energy intakes. American Journal of Clinical Nutrition 1990; 51: 309-15.

8 Bleiberg F, Brun T, Goihman B, Gouba E. Duration of activities and energy expenditure of female farmers in dry and rainy seasons in Upper Volta. British Journal of Nutrition 1980; 43: 71-82.

9 Ferro-Luzzi A, Branca F, Pastore G. Body mass index defines the risk of seasonal energy stress in the third world. European Journal of Clinical Nutrition 1994; 48(Suppl. 3): S165-78.

10 Branca F, Pastore G, Demissie T, Ferro-Luzzi A. The nutritional impact of seasonality in children adults of rural Ethiopia. European Journal of Clinical Nutrition 1993; 47 840-50.

11 Vinoy S, Rosetta L, Mascie-Taylor CGN. Repeated measurements of energy intake, energy expenditure and energy balance in lactating Bangladeshi mothers. Whole body calorimetry. American Journal of Clinical Nutrition 2000; 57: 353-64

12 Adams AM. Seasonal variations in energy balance among agriculturists in central Mali: compromise or adaptation. European Journal of Clinical Nutrition 1995; 49: 809-23.

13 Hegsted DM. Energy needs and energy utilisation. Nutrition Reviews 1974; 32: 33-8.

14 Banerjee S. Studies on Energy Metabolism. Special Report No. 43. New Delhi: Indian Council of Medical Research, 1962.

15 Banerjee B, Khew KS, Saha N. A comparative study of energy expenditure in some common daily activities of non pregnant and pregnant Chinese, Malay and Indian women. Journal of Obstetrics and Gynaecology 1971; 78 113-16.

16 Devdas RP, Anuradha V, Jansi Rani A. Energy intake and expenditure of selected mannual labourers. Indian Journal of Nutrition and Dietetics 1975; 12: 279-84.

17 Sujatha T, Shatrugna V, Venkataramana Y, Bengum N. Energy expenditure on household, childcare and occupational activities of women from urban poor households. British Journal of Nutrition 2000; 83: 497-503.

18 Bhatia BD, Banerjee D, Agarwal DK, Agarwal KN. Dietary intakes of urban and rural pregnant lactating and nonpregnant, non-lactating vegetarian women of Varanasi. Indian Journal of Medical Research 1981; 74: 680-7.

19 Bhargava A, Kwatra BL. Energy and iron status of farm women belonging to middle income group. Journal of Dairy Foods and Home Science 1999; 18: 1-8.

20 Kanade A, Gokhale M, Rao S. Energy costs of standard activities among Indian adults. European Journal of Clinical Nutrition 2001; 55: 708-13.
21 Food and Agriculture Organization/World Health Organization/United Nations University (FAO/WHO/UNU). Energy and Protein Requirements. Report of Joint FAO/WHO/UNU Expert Consultation. Technical Report Series No. 724. Geneva: WHO, 1985

22 Henry CJK, Rees DG. New prediction equations for the estimation of basal metabolic rate in tropical peoples. European Journal of Clinical Nutrition 1991; 45: 177-85.

23 Bleiberg FM, Brun TA, Goihman S, Lippman D. Food intake and energy expenditure of male and female farmers from Upper Volta. British Journal of Nutrition 1981; 45: 505-15.

24 Cilinger C, Aktas N. Energy expenditure and energy nutrient consumption of female textile workers. Nutrition Research 1995; 15: 813-17.

25 Singh J, Prentice A, Diaz E, Coward WA, Ashford J, Sawywe $\mathrm{M}$, et al. Energy expenditure of Gambian women during peak agricultural activity measured by the doubly-labelled water method. British Journal of Nutrition 1989; 62: 315-29.

26 Yuchingtat GP, Guzman MPEDE, Caberera JP, Solano GP, Panugao MP, Gayya CT, et al. A study of energy expenditure, dietary intake and pattern of daily activity among housewives of sugarcane farmers. Philippine Journal of Science 1995; 124: 171-81.

27 Geissler C, Brun T, Mirbagheri I, Soheli A, Naghibi A, Hidayat $\mathrm{H}$. The energy expenditure of carpet weavers and rural women in Iran. American Journal of Clinical Nutrition 1981; 34: 2776-83.

28 Torun B, McGuire J, Mendoza RD. Energy cost of activities and tasks of women from a rural region of Guatemala. Nutrition Research 1982; 2: 127-36.

29 Yamauchi T, Ohtsuka R. Basal metabolic rate and energy costs at rest and during exercise in rural- and urbandwelling Papua New Guinea Highlanders. European Journal of Clinical Nutrition 2000; 54: 494-9.

30 Lawrence M, Singh J, Lawrence F. The energy cost of daily activities in African women: increased expenditure in pregnancy. American Journal of Clinical Nutrition 1985; 42: 753-63.

31 Geissler CA, Mazine S, Aldouri H. Racial differences in the energy cost of standardized activities. Annals of Nutrition $\mathcal{E}$ Metabolism 1985; 29: 40-7.

32 Dufour DL, Reina JC, Spurr GB. Energy intake and expenditure of free living pregnant Colombian women in and urban setting. American Journal of Clinical Nutrition 1999; 70: 269-76.

33 Murgatroyd PR, Goldberg GR, Leahy FE, Gilsenan MB, Prentice AM. Effects of inactivity and diet composition on human energy balance. International Journal of Obesity and Related Metabolic Disorders 1999; 23: 1269-75.

34 Soares MJ, Shetty PS. Validity of Schofield's predictive equations for basal metabolic rates of Indians. Indian Journal of Medical Research 1988; 88: 253-60.

35 Schofield WN, Schofield C, James WPT. Basal metabolic rate - review and prediction, together with an annotated bibliography of source material. Human Nutrition: Clinical Nutrition 1985; 39C(Suppl. 1): 5-96.

36 Rao S, Kanade A, Margetts BM, Yajnik CS, Lubree H, Rege S, et al. Maternal activity in relation to birth size in rural India. The Pune Maternal Nutrition Study. European Journal of Clinical Nutrition 2003; 57: 531-42.

37 Batliwala S. Women in poverty: the energy, health and nutrition syndrome. In: Jain $\mathrm{D}$, Banerjee $\mathrm{N}$, eds. Tyranny of the Household. New Delhi: Modern Printers, 1985; 38-50.

38 Spurr GB, Prentice AM, Murgatroyd PR, Goldberg GR, Reina JC, Christman NT. Energy expenditure from minute-byminute heart rate recording: comparison with indirect calorimetry. American Journal of Clinical Nutrition 1988; 48: 552-9. 
39 Grover I. Effect of dietary intake, maternal factors and socio-economic factors on birth weight of infants in rural Haryana. Indian Journal of Nutrition and Dietetics 1982; 19: 80-6.

40 Piers LS, Diggavi S, Thangam S, Raaij JMA, Shetty P, Hautvast JGAJ. Changes in energy expenditure, anthropometry and energy intake during the course of pregnancy and lactation in well nourished Indian women. American Journal of Clinical Nutrition 1995; 61: 501-13.

41 Hutter I. Reduction of food intake during pregnancy in rural South India. Tropical Medicine \& International Health 1996; 1: 399-405.

\section{Appendix - Description of typical activities for which energy costs were measured}

Carrying water containers on head: Carrying two big metal containers filled with water (total weight about $20 \mathrm{~kg}$ ) on the head and walking from the well to home (a distance of approx. 0.5 to $1 \mathrm{~km}$ ).

Chopping firewood: Chopping dry tree branches, about 2-4 in. in diameter, with a machete (long-bladed knife weighing 2-3 lb), into suitable sized pieces for the chulba (the earthen stove).

Cleaning animal shed: Collecting wet cow dung lumps in a corner of the animal shed, disposing of the dry leaves, wet straws and other garbage on floor; sweeping of the shed is done in a bending position with a short broom. The shed is often wet and marshy, requiring extra energy to clean it.

Cleaning grains: Includes blowing the grains in the wooden tray to remove extraneous matter and cleaning undesirable particles from grain; usually performed in a sitting position.

Cleaning utensils: Includes lifting a bucket full of water, vigorously scouring the utensils with detergent powder to remove grease and food particles from pans and dishes, and rinsing them with water.

Cooking vegetables: Includes washing and cutting the vegetables, then sautéing them on a griddle with frequent stirring. Women often have to make movements within the kitchen to get a knife, spoon, other ingredients, etc.

Fetching water from well: Drawing water from the well using a small plastic/tin bucket attached to a long rope. Pulling up (about $10 \mathrm{~m}$ ) the buckets filled with water (approx. $10 \mathrm{~kg}$ ) in a bending position is a strenuous task as there are hardly any pulleys.
Grinding cereals, grains on millstone: In sitting position, putting a fistful of grain into the millstone, and rotating the millstone in an anticlockwise direction, using the wooden handle, to grind the grains for getting fine flour.

Grinding masala paste: Making a fine paste of groundnuts or sesame seeds and spices by adding little water on a flat stone. This is generally done in squatting position.

Making bajara roties on chulba: Includes kneading bajara (pearl millet) flour by hand to make smooth dough, patting small balls of dough by hand into round pancake, tending while pancakes cook on the griddle and finally roasting them on the fire. While cooking women keep stoking the fire. All the work is done in sitting position in front of the chulha.

Plucking coriander seedlings: Uprooting young coriander plants in the field and tying them into small bunches for selling in the market.

Setting dirt floor with cow dung: Comprises mixing cow dung with water until it becomes a semi-solid slurry and spreading it on the dirt floor by hand, from one end of the room to the other, to make a thin layer. While doing this, women move backwards on their haunches.

De-shelling groundnut pods: Pressing dried groundnut pods on the floor to break the hard shells and removing the nuts.

Stitching clothes on sewing machine: Sitting on a stool of $1 \mathrm{~m}$ height in front of the machine, and stitching the cloth using a sewing machine operated manually by foot.

Sweeping the bouse: Involves walking slowly forwards, holding a broom in partially flexed posture, to sweep the dirt floor.

Washing clothes: The procedure consists of wetting clothes, soaping, scrubbing (anchoring the cloth with one hand and scrubbing with a back-and-forth motion using the other), scooping water and pouring it over the clothes, rinsing and wringing to dry. Dirt is removed from the clothes by the women's physical force. This activity includes squatting and bending posture. Usually carried out either at the doorstep or well, which additionally includes fetching of water from the well.

Weeding: Stooping and removing the weeds between rows of cultivated plants with a small curved knife. 